REVIEW

\title{
Level of Awareness and Knowledge of Breast Cancer in Nigeria. A Systematic Review.
}

\author{
Agodirin S Olayide $^{1 *}$, Akande J Halimat ${ }^{2}$, Olatoke A Samuel ${ }^{1}$ Rahman A \\ Ganiyu' ${ }^{1}$, Oguntola A Soliu ${ }^{3}$
}

\author{
OPEN ACCESS \\ Citation: Agodirin S Olayide, AkandeJ \\ Halimat, Olatoke A Samuel, Rahman A \\ Ganiyu , Oguntola A Soliu . Level of \\ Awareness and Knowledge of Breast \\ Cancer in Nigeria. A Systematic Review. \\ Ethiop J Health Sci 2017;27(1):163. doi: \\ http://dx.doi.org/10.4314/ejhs.v27i2.9 \\ Received: November 24, 2016 \\ Accepted: December 1, 2016 \\ Published: March 1, 2017 \\ Copyright: (C) 2015 Agodirin, et al. This \\ is an open access article distributed under \\ the terms of the Creative Commons \\ Attribution License, which permits \\ unrestricted use, distribution, and \\ reproduction in any medium, provided the \\ original author and source are credited. \\ Funding: Nill \\ Competing Interests: The authors \\ declare that this manuscript was approved \\ by all authors in its form and that no \\ competing interest exists. \\ Affiliation and Correspondence: \\ ${ }^{1}$ Department of Surgery University of \\ Ilorin Teaching Hospital, Ilorin, \\ Nigeria \\ ${ }^{2}$ Department of Radiology, \\ University of Ilorin Teaching \\ Hospital, Ilorin, Nigeria \\ 3Department of Surgery, LAUTECH \\ Ogbomoso, Oyo State,Nigeria \\ "Email: Cancer1992@yahoo.com
}

\section{ABSTRACT}

BACKGROUND: Despite reports of improved awareness of breast cancer entity and seemingly upbeat levels of other awareness subthemes in Nigeria, patients continue to present late when treatment is least rewarding. This paradoxical trend of both rising awareness and late presentation coupled with reports suggesting other competing drivers of late presentation question the "theory of poor awareness" as the foremost driver of late presentations. By aggregating available data, we aimed to assess what still constitutes poor breast cancer awareness in Nigeria in order to suggest how to allocate resources to reverse the paradox

METHOD: Studies conducted on Nigerian populace from 2000 to date were reviewed systematically. Search was made in PROSPERO, PubMed/MEDLINE, AJOL, Cochrane library, GOOGLE, ResearchGate and ACADEMIA. Primary outcome was level of awareness about breast cancer entity.

RESULT: Fifty-one eligible $(48$ descriptive surveys, 3 interventional ones) studies were reviewed. They included 19,598 respondents (98.5\% females; $43 \%$ rural dwellers). 17,086(87.2\%) were laypersons in various walks of life; 2,512(12.8\%) were healthcare professionals. There were high levels of awareness of breast cancer entity, BSE, knowledge of fatality and benefit of early detection (weighted percentages $80.6 \%, 60.1 \%$, $73.2 \%$ and $73.9 \%$ respectively). Weighted percentages of knowledge of symptoms/signs was 45.1\%. Weighted percentages of sense of susceptibility and performance of BSE were low-26.8\% and $22.9 \%$ respectively. Generally, rate of performance of screening did not vary with changes in the level of awareness/knowledge of concepts. CONCLUSION: In general, low awareness of breast cancer may not be the direct and foremost driver of persistent late presentation in Nigeria.

KEYWORDS: Breast cancer, awareness, knowledge, Systematic review, Nigeria 


\section{INTRODUCTION}

The great improvements in outcome of breast cancer (BC) management in High Income Centers (HIC) is credited largely to early diagnosis which accompany widespread awareness and uptake of screening. The improvement in survival experienced in such centers is transforming BC to just another chronic illness with focus of management now shifting towards coping with long term survival. In contrast, BC remains a catastrophic illness in Low and Middle Income Centers (LMIC); the top 10 highest mortality rates from breast cancer are recorded in LMIC and Nigeria is third on the list (1).

In Nigeria, the failure being experienced in $\mathrm{BC}$ control is not from inactivity. Awareness is expected to vary inversely with the duo of late presentation and poor outcome hence enormous resources is expended on awareness boosting programs (2-6) as the bedrock of the fight against BC. Yet the high rate of late of presentations persists $(7,8)$.

Despite increasing reports of growing awareness of $\mathrm{BC}$ as an entity $(5,7,8)$ and equivocal but seemingly upbeat levels of other awareness subthemes (3,9-12), tertiary centers in Nigeria continue to receive patients at late stages when treatment is least rewarding (13). A recent report from Northern Nigeria reported $99 \%$ late presentation (14). This paradoxical trend of both growing awareness and persisting late presentation coupled with reports suggesting other competing drivers of late presentation question the "theory of poor awareness" as the foremost driver of the persistent late presentations.

Therefore, the aim of this review was to assess the level of awareness of $\mathrm{BC}$ and what still constitutes poor awareness of $\mathrm{BC}$ among Nigerian populace by aggregating available data on breast cancer awareness or knowledge. Unveiling the true role of awareness and defining the relationship between the levels of its subthemes will guide allocation of resources, design of specific campaign slogans and development of guidelines for breast-cancer-risk groups and health-care workers interactions.

\section{METHODS}

Search strategy and data sources: The search was conducted in three steps: the preliminary scoping and registration search, the detailed electronic search and the handsearch/snowballing. Preliminary scoping search and registration[registration no: 42016039869] in PROSPERO, an international register of prospective systematic reviews held by the University of York's center for Reviews and Dissemination, confirmed that no similar systematic review was on-going or had been conducted recently. A preliminary scoping search in PubMed/MEDLINE identified search terms in preparation for detailed electronic search. The elected search terms were combined with Boolean operators for detailed electronic search in PubMed/MEDLINE(NCBI), EBSCOhost, Cochrane library, as "(breast cancer AND Nigeria) AND (awareness OR attitude OR perception OR knowledge OR practice OR screening OR behavior OR self-breast examination)" and in African Journals Online(AJOL) advanced search box as "breast AND awareness OR attitude OR perception OR knowledge OR practice OR screening OR behavior OR self-breast examination)". Based on the eligibility criteria, initial screening of article titles and abstracts identified from the detailed electronic search was conducted. Further search in PubMed Central, google, google scholar, ACADEMIA and ResearchGate was conducted by hand-searching plus snowballing on references of the articles that fit the eligibility criteria. Attempt was made to contact corresponding authors of articles not freely available in full. The search process opened on the $23^{\text {rd }}$ of May 2016 and concluded on the $9^{\text {th }}$ of July 2016.

Quality assessment and data extraction: Quality assessment preceded data extraction. Both processes employed specially designed forms. The data extraction form collected information about level of awareness of $\mathrm{BC}$ as an entity, awareness and performance of screening, knowledge of symptoms and risk factors of $\mathrm{BC}$, awareness of severity of $\mathrm{BC}$ and awareness of benefit of screening and early detection. The detailed electronic search, quality assessment and data

DOI: http://dx.doi.org/10.4314/ejhs.v27i2.9 
extraction were conducted independently by two separate reviewers (ASO and $\mathrm{AHJ}$ ) after initial training pilot sessions. The results obtained by the independent reviewers were harmonized. A third reviewer, OSA, was the tie-breaker. The quality assessment form was adapted from the STROBE statement checklist for observational studies (15) to suit the review requirements. Reviewers were not blinded to authors of the articles.

Analysis: Extracted data were imputed into SPSS $\mathrm{v} 16$ and $\mathrm{R}$ version 3.2.2 statistical package. Weighted percentages of the level of various concepts were calculated. Results were presented in descriptive statistics using SPSS v16 and R statistical software. The report was presented according to the PRISMA recommendations (16).

\section{RESULTS}

The detailed online electronic search using the elected keywords/MeSH terms yielded a total initial hit of 413 articles of which 18 were duplicates. Sixty-two articles were eligible after the initial title and abstract review and snowballing/hand-searching. Among the 62, fortynine were available in full on-line; one of the 49 article was stored and reviewed as two independent articles with two separate groups of respondents (17) because of its method and reporting pattern. Correspondence with two responsive authors yielded three articles but only two were eligible for inclusion after review of the full articles, making a total of 52 full articles. Five authors did not respond, and five could not be reached (Figure 2.). One of the 52 full article was excluded after full article review because it was difficult to aggregate and extract data for this review (9) (Figure 1).

The 51 eligible surveys (48 descriptive, 3 interventional) (see references in quality assessment table) included 19,598 respondents (98.5\% females, $43 \%$ rural dwellers). Thirtyseven studies involved 17,086(87.2\%) respondents from various walks of life (Table 1), while 14 studies involved 2,512(12.8\%) respondents who were healthcare professionals including nursing students and medical students. Respondents recorded as students represented secondary school students, tertiary institution undergraduates and postgraduates excluding nursing students and medical students. Respondents recorded as teachers were secondary school teachers. Respondents recorded as health workers were mixed populations of doctors, nurses and other health professionals (pharmacists, radiographers, laboratory technicians, community health extension workers, environmental health assistants). Those recorded as laypersons included traders, farmers, secondary school students, artisans, non-health professionals, civil servants and unemployed persons. Outpatients attendees included persons attending surgery outpatient clinics, general practice outpatient clinics, immunization clinics and antenatal clinics. Respondents recorded as rural dwellers had similar composition as laypersons, but most were traders, farmers and artisans.

The minimum number of subjects in any one study was 18 conducted among medical students, and the maximum was 2048 conducted among rural dwellers. Only two of the surveys included males; one included both sexes, 99 of whom were males (18) and the other was conducted solely in 217 married men (66). Overall, the youngest respondent was 12 years old while the oldest was 86 years old. Twenty-five surveys $(45.7 \%$ of respondents) were $12-50$ years, 19 studies (26.8\% of respondents) were 12-70 years and 7 surveys $(25.7 \%$ of respondents) were $12-86$ years. Eighteen of the studies were conducted in rural settings, 26 in urban settings and 7 in semi-urban settings. Regarding distribution among the three major tribal units in Nigeria, 27 of the studies were conducted among the Yorubas-mainly Southern states, 15 among Igbos-mainlyEastern states and 9 among the Hausas-mainly Northern states.

DOI: http://dx.doi.org/10.4314/ejhs.v27i2.9 


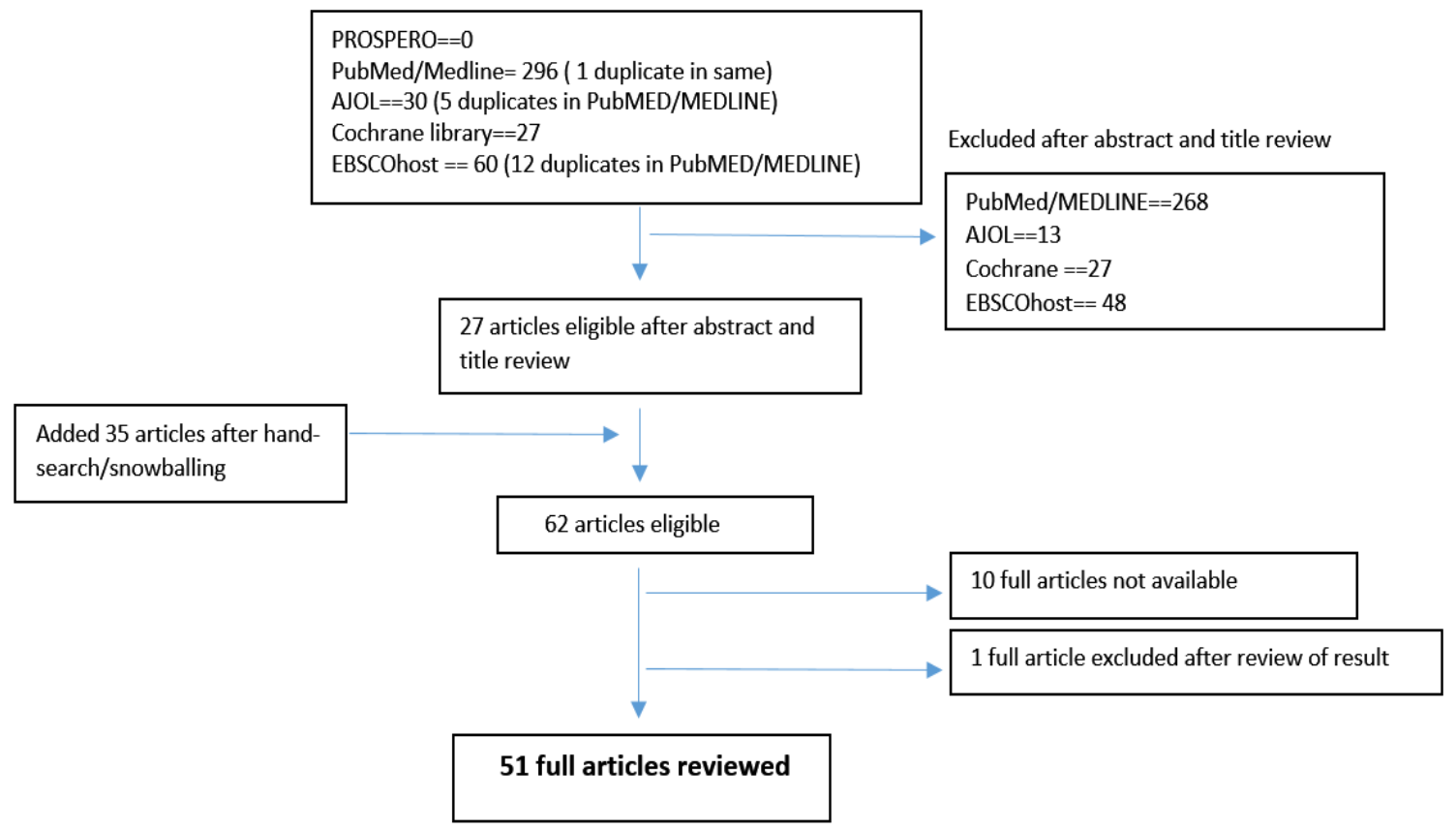

Figure 1: Flow chart of systematic search

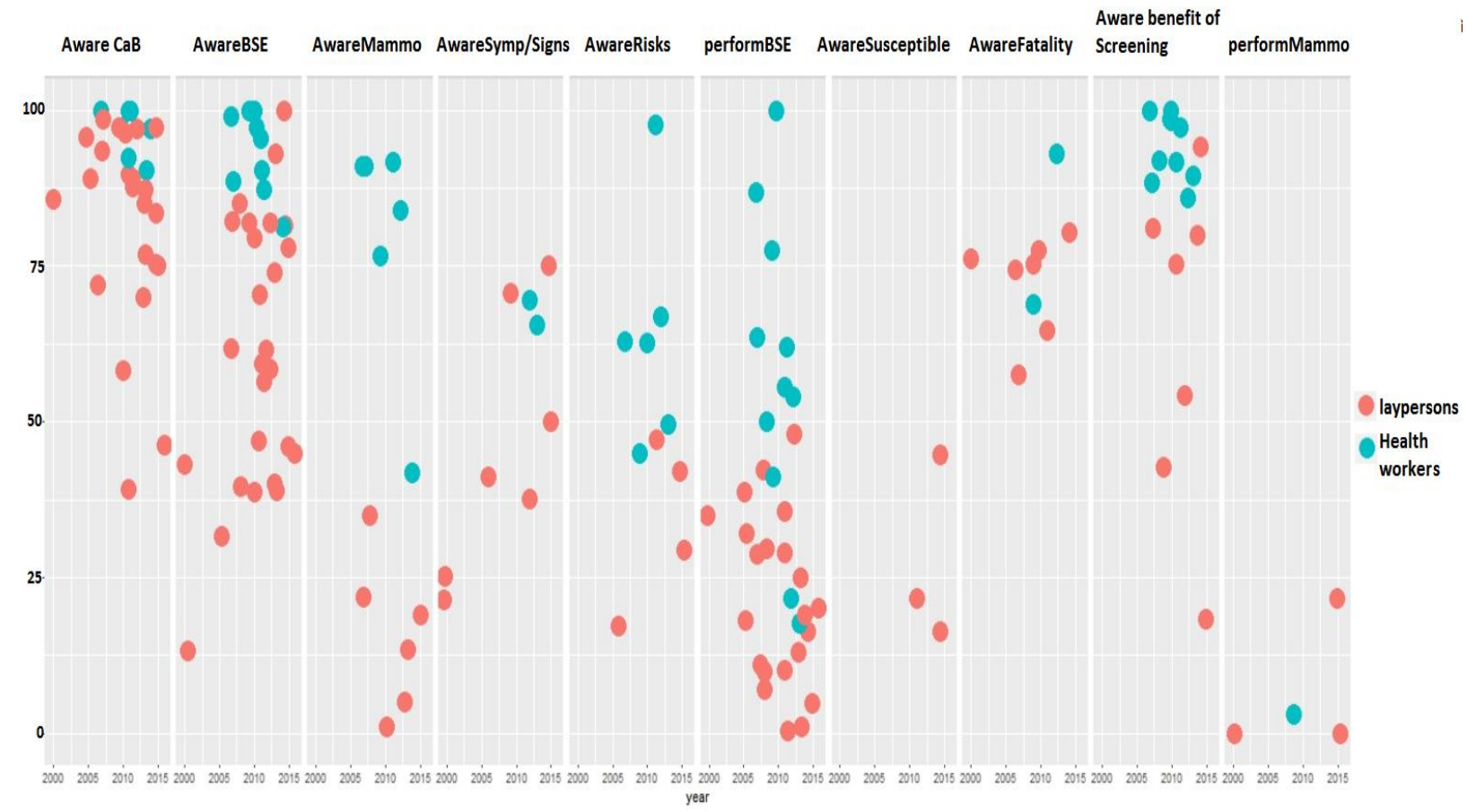

Figure 2: Relationship between subthemes of awareness of breast cancer

DOI: http://dx.doi.org/10.4314/ejhs.v27i2.9 
Table 1: Distribution of respondents

\begin{tabular}{lllll}
\hline Respondents & $\begin{array}{l}\text { No of } \\
\text { studies }\end{array}$ & $\begin{array}{l}\text { Minimum no of } \\
\text { respondents per } \\
\text { study }\end{array}$ & $\begin{array}{l}\text { Maximum no of } \\
\text { respondents per } \\
\text { study }\end{array}$ & $\begin{array}{l}\text { Total sum of } \\
\text { respondents in } \\
\text { review }\end{array}$ \\
\hline $\begin{array}{l}\text { Students } \\
\text { School teachers }\end{array}$ & 11 & 200 & 700 & 3125 \\
$\begin{array}{l}\text { Healthcare workers (mixed } \\
\text { population of nurses, doctors and } \\
\text { other health professionals) }\end{array}$ & 8 & 100 & 326 & 726 \\
$\begin{array}{l}\text { Rural dwellers } \\
\text { Nurses }\end{array}$ & 100 & 424 & 1868 \\
$\begin{array}{l}\text { Lay women } \\
\text { Market women }\end{array}$ & 4 & 100 & & \\
$\begin{array}{l}\text { Outpatient clinic attendees (both } \\
\text { sexes) }\end{array}$ & 5 & 203 & 2048 & 4465 \\
Medical students & 5 & 238 & 135 & 426 \\
Nursing students & 140 & 1600 & 4711 \\
\hline Grand total & 1 & 18 & 1194 & 2316 \\
\hline
\end{tabular}

The quality assessment showed that the period of study was not stated in $52 \%$ of the studies. In $44 \%$, there was no explicit question to establish the level of awareness of breast cancer as a disease entity before further questioning (Table 3). All the studies specified their aim but relevance of the study was not clear in some studies, and sample size justification was lacking in many of the studies (Table 2). Overall, one study was rated excellent quality (quality assessment of 100\%), 22 studies were rated high quality (quality assessment score of more than $80-99 \%$ ), 18 studies were rated moderately high quality (quality assessment score between $70 \%$ and $79 \%$ ) and 8 were rated marginal quality (quality assessment score of between $60 \%$ and 69\%) (Table3). However, one of the studies was rated low quality (quality assessment score less than $60 \%$.

The mean $( \pm \mathrm{SD})$ level of awareness of breast cancer as a disease entity was $85.7 \pm 16.3 \%$, the mean level of awareness of breast selfexamination and mammography as methods of screening for breast cancer were $73.36 .3 \pm 24.1 \%$ and $48 \pm 20.1$ respectively. The knowledge of risk factors for breast cancer was higher than the knowledge of symptoms. The percentages of respondents who performed breast selfexamination regularly as screening procedure were higher than those who performed mammography (Table 3) as recommended in practice for the appropriate age brackets.

The scatterplot (Figure 2) shows a high level of awareness of the entity, high level of knowledge of fatality, mid-range level of knowledge of clinical features and risk factors and low level of sense of susceptibility and performance of screening procedures. The levels of all subthemes of awareness were higher among the health care workers. 
Table 2: Quality assessment

\begin{tabular}{|c|c|c|c|c|c|c|c|c|c|c|c|}
\hline Author & Aim & $\begin{array}{l}\text { Relevan } \\
\text { ce }\end{array}$ & $\begin{array}{l}\text { Subject } \\
\text { Selection } \\
\text { method } \\
\text { well stated }\end{array}$ & $\begin{array}{l}\text { Subjec } \\
\text { ts well } \\
\text { stated }\end{array}$ & $\begin{array}{l}\text { Sample } \\
\text { Size } \\
\text { justified }\end{array}$ & $\begin{array}{l}\text { Questionnaire } \\
\text { type and } \\
\text { administration } \\
\text { method well } \\
\text { stated }\end{array}$ & $\begin{array}{l}\text { Period } \\
\text { Of study } \\
\text { stated }\end{array}$ & $\begin{array}{l}\text { Awareness } \\
\text { Of breast } \\
\text { cancer } \\
\text { entity noted }\end{array}$ & $\begin{array}{l}\text { Results } \\
\text { Ease of } \\
\text { extraction }\end{array}$ & $\begin{array}{l}\text { Ethical } \\
\text { consid } \\
\text { eration }\end{array}$ & quality \\
\hline Agboola et al (41) & 1 & 1 & 0 & 0.5 & 0 & 1 & 1 & 1 & 1 & 1 & 75 \\
\hline Akhigbe et al (24) & 1 & 1 & 1 & 0.5 & 0.5 & 0.5 & 1 & 0 & 1 & 1 & 75 \\
\hline Akpo et al(42) & 1 & 1 & 1 & 1 & 0 & 1 & 1 & 0 & 1 & 1 & 80 \\
\hline Amoran et al (25) & 0.5 & 0.5 & 1 & 1 & 1 & 1 & 1 & 0 & 1 & 1 & 80 \\
\hline Amosu et al(43) & 1 & 1 & 0 & 1 & 0 & 1 & 0 & 0 & 0.5 & 1 & 55 \\
\hline Azubuike e al (44) & 1 & 1 & 1 & 1 & 1 & 0.5 & 1 & 1 & 0.5 & 1 & 90 \\
\hline Azubuike et al(7) & 1 & 1 & 0.5 & 1 & 0 & 0.5 & 0 & 0.5 & 1 & 1 & 65 \\
\hline Balogun et al(45) & 1 & 1 & 1 & 1 & 0 & 1 & 0 & 0 & 1 & 1 & 70 \\
\hline Bassey et al (46) & 1 & 1 & 1 & 0.5 & 0 & 1 & 1 & 1 & 1 & 1 & 85 \\
\hline Bello et al(17) & 1 & 0.5 & 0.5 & 0.5 & 0 & 1 & 1 & 1 & 1 & 1 & 75 \\
\hline Eguvbe et al (34) & 1 & 1 & 1 & 1 & 0 & 1 & 1 & 1 & 0.5 & 1 & 85 \\
\hline Faronbi et al(47) & 1 & 1 & 1 & 1 & 0 & 1 & 0 & 0 & 1 & 1 & 70 \\
\hline Gwarzo et al(48) & 1 & 1 & 1 & 0.5 & 1 & 1 & 1 & 1 & 1 & 1 & 95 \\
\hline Ibrahim et al(49) & 1 & 1 & 1 & 0.5 & 1 & 1 & 1 & 0 & 1 & 1 & 85 \\
\hline Irurhe et al(50) & 1 & 0 & 1 & 1 & 1 & 0.5 & 1 & 1 & 1 & 0.5 & 80 \\
\hline Isara et al(28) & 1 & 1 & 0.5 & 1 & 0 & 1 & 1 & 1 & 1 & 1 & 85 \\
\hline Kayode(51) & 1 & 0.5 & 1 & 1 & 0 & 1 & 0 & 1 & 1 & 1 & 75 \\
\hline Makanjuola et al(52) & 1 & 1 & 0 & 1 & 0 & 1 & 1 & 1 & 1 & 1 & 80 \\
\hline Obaji et al(53) & 1 & 0 & 0.5 & 1 & 0 & 1 & 0 & 1 & 1 & 1 & 65 \\
\hline Obajimiet al(35) & 1 & 1 & 1 & 1 & 1 & 0.5 & 0 & 0 & 1 & 1 & 75 \\
\hline Ocheet al(54) & 1 & 1 & 1 & 1 & 1 & 1 & 0 & 1 & 1 & 0.5 & 85 \\
\hline Oguntola et al(18) & 1 & 0.5 & 0 & 1 & 0 & 1 & 1 & 1 & 1 & 1 & 75 \\
\hline Okobiaet al(55) & 1 & 0.5 & 1 & 1 & 1 & 0.5 & 1 & 0 & 1 & 1 & 80 \\
\hline Okolie(56) & 1 & 1 & 0 & 1 & 0 & 1 & 1 & 1 & 1 & 1 & 80 \\
\hline Oladimeji et al (57) & 1 & 0.5 & 1 & 0.5 & 1 & 1 & 1 & 0 & 0.5 & 1 & 75 \\
\hline Olugbenga et al(30) & 1 & 1 & 1 & 0.5 & 1 & 1 & 0 & 1 & 1 & 1 & 85 \\
\hline Oluwatosin et al (8) & 1 & 1 & 1 & 0.5 & 1 & 1 & 0 & 1 & 1 & 1 & 85 \\
\hline Oluwatosin et al (31) & 1 & 1 & 1 & 1 & 0 & 1 & 1 & 0 & 1 & 1 & 80 \\
\hline Oluwole(58) & 1 & 0.5 & 1 & 1 & 0 & 1 & 1 & 0 & 0.5 & 1 & 70 \\
\hline Omotara et al (59) & 1 & 1 & 1 & 1 & 1 & 1 & 1 & 1 & 1 & 1 & 100 \\
\hline Salaudeen et al(60) & 1 & 0 & 1 & 1 & 0 & 1 & 0 & 1 & 1 & 1 & 70 \\
\hline
\end{tabular}

DOI: http://dx.doi.org/10.4314/ejhs.v27i2.9 
Table 2 continued...

Utoo et al(61)

Adegbenro et al (23)

Chioma et al(62)

Yakubu et al(10)

Ogunbode et al(36)

Aluko et al(63)

Abazie et al (29)

Asuquo et al (64)

Ezeonu et al(65)

Isichei et al(5)

Tobin et al(2)

Neji et al(4)

Iheanacho et al

Adeoti et al (66)

Osime et al (67)

Aderounmu et al (68)

Bellgam et al(69)

Sambo et al(32)

Ajayi et al(70)

$\begin{array}{ll}1 & 1 \\ 1 & 0 \\ 1 & 1 \\ 1 & 1 \\ 1 & 0.5 \\ 1 & 0 \\ 1 & 1 \\ 1 & 1 \\ 1 & 1 \\ 0.5 & 0 \\ 1 & 0 \\ 1 & 1 \\ 1 & 1 \\ 1 & 0.5 \\ 1 & 1 \\ 1 & 1 \\ 1 & 0.5 \\ 0.5 & 0 \\ 1 & 0\end{array}$

$\begin{array}{lll}1 & 0.5 & 0 \\ 1 & 1 & 1 \\ 1 & 1 & 0 \\ 0 & 1 & 0 \\ 1 & 1 & 1 \\ 1 & 1 & 1 \\ 1 & 1 & 1 \\ 1 & 1 & 1 \\ 1 & 1 & 1 \\ 1 & 1 & 0 \\ 1 & 1 & 1 \\ 1 & 1 & 1 \\ 1 & 0 & 1 \\ 1 & 1 & 0 \\ 0.5 & 1 & 0 \\ 1 & 0.5 & 0 \\ 1 & 1 & 0 \\ 1 & 1 & 0 \\ 1 & 1 & 0\end{array}$

$\begin{array}{ll}0 & 1 \\ 1 & 1 \\ 0 & 1 \\ 0 & 1 \\ 1 & 1 \\ 1 & 1 \\ 1 & 1 \\ 1 & \\ 1 & \\ 0 & \\ 1 & \\ 1 & \\ 1 & \\ 0 & \\ 0 & \\ 0 & \\ 0 & \\ 0 & \\ 0 & \end{array}$

$\begin{array}{ll}1 & 0 \\ 1 & 1 \\ 1 & 0 \\ 1 & 1 \\ 1 & 1 \\ 1 & 0 \\ 1 & 0 \\ 1 & 0 \\ 1 & 0 \\ 1 & 0 \\ 1 & 0 \\ 1 & 0 \\ 1 & 0 \\ 1 & 0 \\ 1 & 0 \\ 1 & 0 \\ 1 & 1 \\ 1 & 0 \\ <60>10 W\end{array}$

\begin{tabular}{llll}
0 & 1 & 1 & 65 \\
1 & 1 & 0.5 & 85 \\
1 & 1 & 0.5 & 75 \\
0 & 1 & 1 & 70 \\
0 & 0.5 & 1 & 80 \\
0 & 1 & 1 & 70 \\
0 & 1 & 1 & 80 \\
1 & 0 & 1 & 80 \\
1 & 1 & 1 & 90 \\
1 & 1 & 0.5 & 60 \\
0 & 1 & 1 & 70 \\
1 & 1 & 1 & 90 \\
0 & 0 & 1 & 60 \\
0 & 1 & 1 & 65 \\
0 & 0.5 & 1 & 60 \\
1 & 1 & 1 & 75 \\
0 & 1 & 1 & 75 \\
1 & 0.5 & 1 & 60 \\
1 & 1 & 1 & 70 \\
\hline
\end{tabular}

Quality assessment legend: $100=>$ excellent, $80-99=>$ high, $70-79=>$ moderate high, $60-69=>$ marginal, $<60=>$ low 
Table 3: Summary statistics of level of subthemes of awareness

\begin{tabular}{llllll}
\hline Concept in awareness & $\begin{array}{l}\text { No of } \\
\text { studies }\end{array}$ & $\begin{array}{l}\text { Minimum } \\
\text { percentage } \\
\text { Possessing } \\
\text { concept }\end{array}$ & $\begin{array}{l}\text { Maximum } \\
\text { percentage } \\
\text { Possessing } \\
\text { concept }\end{array}$ & $\begin{array}{l}\text { Average } \\
\text { percentage }\end{array}$ & $\begin{array}{l}\text { Weighted } \\
\text { percentage }\end{array}$ \\
\hline $\begin{array}{l}\text { Awareness of BC the } \\
\text { breast as a disease entity }\end{array}$ & 31 & 39.2 & 100 & $85.9 \pm 15.5$ & 80.7 \\
$\begin{array}{l}\text { Awareness of BSE as a } \\
\text { screening method }\end{array}$ & 35 & 13.3 & 100 & $69.3 \pm 23.8$ & 60.7 \\
$\begin{array}{l}\text { Awareness of } \\
\text { mammography as a }\end{array}$ & 12 & 1 & 91.8 & $37.8 \pm 36.5$ & 36.9 \\
$\begin{array}{l}\text { screening method } \\
\text { Knew symptoms and }\end{array}$ & 9 & 21.4 & 75 & $50.6 \pm 20.4$ & 45.1 \\
$\begin{array}{l}\text { signs } \\
\text { Knew risk factors }\end{array}$ & 10 & 17.4 & 97.6 & $52 \pm 22.16$ & 40 \\
$\begin{array}{l}\text { Knew BC is a } \\
\text { fatal/severe disease } \\
\text { accepted susceptibility }\end{array}$ & 3 & 57.6 & 93 & $74.3 \pm 10.0$ & 73.2 \\
$\begin{array}{l}\text { Knew screening/early } \\
\text { treatment is beneficial }\end{array}$ & 17 & 16.3 & 44.8 & $27.6 \pm 15.1$ & 26.8 \\
$\begin{array}{l}\text { Regularly performed } \\
\text { BSE }\end{array}$ & 33 & 0.5 & 100 & $81.7 \pm 22.8$ & 74 \\
$\begin{array}{l}\text { Regularly Performed } \\
\text { screening } \\
\text { mammography }\end{array}$ & 3 & 0 & 100 & $33.5 \pm 24.8 .0$ & 22.9 \\
\hline
\end{tabular}

\section{DISCUSSION}

The rate of late presentation of $\mathrm{BC}$ has remained persistently high in Nigeria despite growing awareness. The leading cause of the late presentation is becoming contentious; the reasons competing for dominance are lack of awareness, fear of treatment coupled with non-acceptance of treatment or preference for alternative therapy, poverty and ignorance. In a study by Khan et al (19) among Pakistani women, the highest ranking reason for late presentation was preference for alternative care, while in a study by Goncalves et al(20) among Brazilian women, the most frequent barriers responsible for delays in breast cancer care were hospital related.

The factors leading to delay in the management of breast cancer may ensue before diagnosis or after diagnosis. The factors leading to delay in either of these periods may be patient related or system related $(21,22)$. Some recognized subthemes of awareness contributing to delays before diagnosis are poor knowledge about the disease and its clinical features, poor sense of susceptibility, poor sense of fatality and poor knowledge of benefit of screening. After diagnosis, poor knowledge of benefit of screening, poor knowledge of fatality of the disease and mistrust of hospital are factors leading to delays in presentation. The finding in this review showed mostly high level of awareness of breast cancer as a disease entity, high level of perception of severity of the disease and high sense of benefit of screening. The knowledge of the clinical features and the risk factors for BC were mostly low and midrange (Figure 2). Commenting on the overall aggregate, these findings imply that the information necessary to arm the respondents against late presentation was not really hidden, but the expected behavioral change, i.e. performance

DOI: http://dx.doi.org/10.4314/ejhs.v27i2.9 
of screening, which is expected to promote early detection was low.

In the studies reviewed, many authors who reported high level of other subthemes but low levels of the knowledge of risk reported low level of performance of screening procedures. Likewise, many who reported high levels of awareness of the various subthemes including knowledge of clinical features and risks also reported low level of performance of screening procedures. Most who reported low level of knowledge of clinical features and risk factors blamed the same for low level of performance of screens (23-28), while most who reported higher levels of knowledge of clinical features and risk factors reasoned that knowledge was not translated to health seeking behavior (29-32). In a simple term, collectively, the rate of performance of screening appeared to be resistant to changes in the levels of awareness or knowledge.This makes us share the view that awareness does not translate into knowledge of risks and knowledge of risks will not automatically translate to positive health-seeking behavior $(6,28,33)$.We also share the view that there are other conditions (third factor(s)) which would be satisfied before awareness and knowledge can positively influence the rate of performance of screening as suggested in the health belief model.

The health care workers among the respondents in the studies reviewed had relatively higher level of performance of breast selfexamination. Others who had been previously recognized to have relatively higher rate of performance of screening were women who had family history of $\mathrm{BC}$, women who had previous history of breast pathologies and women who had been exposed to clinical breast examination (3436). In general, this review suggests a dissociation between awareness and performance of screening.

If the knowledge of clinical features and risk factors carry more weight than other subthemes such as awareness of the entity, awareness of breast self-examination, perception of benefit of screening and fatality of the disease, awareness may be regarded as a foremost factor still propelling late presentation of breast cancer in Nigeria. Nonetheless, more doubts are cast on the leading role of awareness when recent studies suggest fear of mastectomy and other hospital related factors as frequent reasons for delays in management of breast cancer (20,22,37-40).

In conclusion, our study showed that awareness of $\mathrm{BC}$ as an entity and most of the other subthemes of awareness was not low among respondents in the studies reviewed. It also showed that the level of awareness subthemes did not always directly influence the performance of breast cancer screening procedure among the respondents. While awareness themes could still be strong factors, it is paramount at this time, to commit more resources to interventional researches which will bridge the gap between knowledge and positive breast health behaviors. As the knowledge of clinical features and risks were low, we suggest that awareness boosting programs focus more on communicating the clinical features and risk factors of breast cancer.

\section{REFERENCES}

1. Balogun OD, Formenti SC. Locally advanced breast cancer - strategies for developing nations. Front Oncol. 2015;5:89.

2. Tobin E, Okeowo P. Breast self examination among secondary school teachers in south-south Nigeria: A survey of perception and practice. Journal of Public Health and Epidemiology. 2014;6(5):169-73.

3. Bello M. Awareness is the first step in battle against breast cancer. Bulletin of the World Health Organization. 2012;90(3):164-5.

4. Neji OE, E. Kalu, U. Bamidele, E. Breast cancer awareness and practice of breast self examination among women in Adiabo community in Odukpani local government area of Cross River State, Nigeria. Clinical Nursing Studies. 2016;4(1):50-6.

5. Isichei, M. Abubakar, A. Increasing uptake of basic breast examination procedures through breast cancer awareness in Jos Nigeria Journal of Health Medicine and Nursing 2015;16:24-6.

6. Olajide TU, A. Habeebu, M. Lawal, A. Afolayan, M. Mofikoya, M. Awareness and practice of breast screening and its impact on early detection and presentation among breast cancer patients attendign a clinic in lagos, Nigeria. Niger $J$ Clin Pract. 2014;17:802-7.

7. Azubuike S, Okwuokei S. Knowledge, attitude and practices of women towards breast cancer in benin city, Nigeria. Ann Med Health Sci Res. 2013;3(2):155-60. 
8. Oluwatosin OA, Oladepo O. Knowledge of breast cancer and its early detection measures among rural women in Akinyele Local Government Area, Ibadan, Nigeria. BMC Cancer. 2006;6:271.

9. Ojikutu RA, A. Awareness of women about breast cancer in Lagos state, Nigeria. Pak J life soc sci. 2009;7(1):78-85.

10. Yakubu AG, A. Sheshe, A. . Knowledge, Attidude and practice of breast self-examination among female nurses in Aminu Kanu teaching hospital, Kano. Nigeria. Niger J Basic Clin Sci. 2014;11:858. Available from: http://www.njbcs.net/text.asp?2014/11/2/85/14034 4.

11. Odusanya OO, Tayo OO. Breast cancer knowledge, attitudes and practice among nurses in Lagos, Nigeria. Acta oncologica (Stockholm, Sweden). 2001;40(7):844-8.

12. Odusanya OO. Breast cancer: knowledge, attitudes, and practices of female schoolteachers in Lagos, Nigeria. Breast J. 2001;7(3):171-5.

13. Sharma K, Costas A, Shulman LN, Meara JG. A systematic review of barriers to breast cancer care in developing countries resulting in delayed patient presentation. J Oncol. 2012;2012:121873.

14. Agbo S, Oboirien M, Gana G. Breast Cancer Incidence in Sokoto, Nigeria. ISDS Journals. 2013;2(2):1614-22.

15. von Elm E, Altman DG, Egger M, Pocock SJ, Gotzsche PC, Vandenbroucke JP, et al. The Strengthening the Reporting of Observational Studies in Epidemiology (STROBE) Statement: guidelines for reporting observational studies. Int J Surg. 2014;12(12):1495-9.

16. Liberati A, Altman DG, Tetzlaff J, Mulrow C, Gotzsche PC, Ioannidis JP, et al. The PRISMA statement for reporting systematic reviews and meta-analyses of studies that evaluate health care interventions: explanation and elaboration. PLoS Med. 2009;6(7):e1000100.

17. Bello TO, Olugbenga-Bello AI, Oguntola AS, Adeoti ML, Ojemakinde OM. Knowledge and practice of breast cancer screening among female nurses and lay women in Osogbo, Nigeria. West Afr J Med. 2011;30(4):296-300.

18. Oguntola AS, Olaitan PB, Omotoso O, Oseni GO. Knowledge, attitude and practice of prophylactic mastectomy among patients and relations attending a surgical outpatient clinic. Pan Afr Med J. 2012;13:20.

19. Khan MH, S. Iqbal, S. Shahzad, M. Shafique, S. Presentation delay in breast cancer patients and its association with sociodemographic factors in North Pakistan. Chin J Cancer Res. 2015;27(3):288-93.
20. Goncalves LT, G. Almeida, A. Guimaraes, M. Gois, C. Barriers in health care to breast cancer: perception of women. Rev esc enferm 2014;48(3).

21. Unger-saldana K. Challenges to teh early diagnosis and treatment of breast cancer in developing countries. World J Clin Oncol 2014. 2014;5(3):465-77.

22. Akanbi OO, A. Adeoti, M. Aderounmu, A. Idris, O. Abayomi, O. Delay presentation of breast cancer: A study among south western Nigerian women. International Journal of Current Research. 2015;7.

23. Adegbenro C, Ajala A, Ajayi O, Ajayi T, Ajayi E, Ajewole A, et al. Awareness of breast cancer and practice of breast self-examination among rural women in Ife-north local government area Osun state, southwest Nigeria Journal of community medicine and primary health care. 2014;26(1):7687.

24. Akhigbe AO, Omuemu VO. Knowledge, attitudes and practice of breast cancer screening among female health workers in a Nigerian urban city. BMC Cancer. 2009;9:203.

25. 25. Amoran E, Toyobo T, Fatugase O. Breast cancer screening awareness and practice among women in sagamu local government: south western Nigeria, a community based study. British Journal of Applied Science \& Technonlogy. 2014;4(14):2320-32.

26. Aniebue P, Aniebue U. Awareness of breast cancer and breast self examination among female secondary school teachers in Enugu Metropolis South Eastern Nigeria. J Coll Med. 2008;13(2):105-10.

27. Iheanacho PN, A. Emenike, A. Awaremess of breast cancer risk factors and practice of breast self examination among female undergraduates in university of Nigeria Enugu Campus. Open Journal of Nursing. 2013;3:147-52.

28. Isara $A R$, Ojedokun CI. Knowledge of breast cancer and practice of breast self examination among female senior secondary school students in Abuja, Nigeria. J Prev Med Hyg. 2011;52(4):18690.

29. Abazie OO, O. Perceived health believes of breast cancer and knowledge of its early detection measures among rural women in Umuduru Mbano, Imo state. academic Journals. 2014;6(4):148-57.

30. Olugbenga-Bello A, Oladele EA, Bello TO, Ojo JO, Oguntola AS. Awareness and breast cancer risk factors: perception and screening practices among females in a tertiary institution in Southwest Nigeria. Niger Postgrad Med J. 2011;18(1):8-15. 
31. Oluwatosin O. Primary health care nurses' knowledge practice and client teaching of early detection measures of breast cancer in Ibadan. BMC nursing. 2012;11:22.

32. Sambo II, S. Dahiru, I. Knowledge and practice of self breast examination among female undergraduate students in a Northern Nigeria University. JMBR. 2013;12(2):62-8.

33. Gupta A, Shridhar K, Dhillon PK. A review of breast cancer awareness among women in India: Cancer literate or awareness deficit? Eur J Cancer. 2015;51(14):2058-66.

34. Eguvbe A, Akpede A, Arua N. Knowledge of breast cancer and need for its screening among female healthcare workers in Oshimili south local government council area of delta state, Nigeria. AFRIMEDIC Journal. 2014;5(1):59-64.

35. Obajimi MO, Ajayi IO, Oluwasola AO, Adedokun BO, Adeniji-Sofoluwe AT, Mosuro OA, et al. Level of awareness of mammography among women attending outpatient clinics in a teaching hospital in Ibadan, South-West Nigeria. BMC Public Health. 2013;13:40.

36. Ogunbode AM, Fatiregun AA, Ogunbode OO. Breast self-examination practices in Nigerian women attending a tertiary outpatient clinic. Indian J Cancer. 2015;52(4):520-4.

37. Babatunde AS, B. Agboola, J. Nwokoro, C. Belief and practices associated with late presentation in patients with breast cancer; an observational study of patients presenting in a tertiary care facility in Southwest Nigeria. African Journal of Cancer. 2015;7(4):178-85.

38. Clegg-Lamptey JD, J. Attobra, Y. Why do breast cancer patients report late or abscond durign treatmetn in Ghana? A pilot study. Ghana Medical Journal. 2009;43(3):123-31.

39. 39. Dey S. Preventing breast cancer in LMICs via screenign and /or early detection: the real and the surreal. World J Clin Oncol. 2014;5(3):509-19.

40. Agodirin OR, G. Olatoke, S. Adeoti, M. Oguntola, A. The Impact of failed communication on the treatment of the the breast; A case series. Tropical Journal of Health Sciences. 2014;21(1):28-31.

41. Agboola A, Deji-Agboola A, Oritogun K, Musa A, Oyedejo T, Ayoade B. Knowledge, Attitude and practice of breast self examination in female health workers in Olabisi Onabanjo University Teaching Hospital Sagamu Nigeria. International Medical Journal. 2009;2(1).

42. Akpor E, Akpor M, Akhator A. breast cancer knowledge and screening practices among Nigerian Medical students. Internet Journal of Health. 2009;11(2):1-8.
43. Amosu A, Degun A, Thomas a, Babalola O. Assessment of awareness, perception, specific knowledge, and screening behavior regarding breast cancer among rural women in Ipokia local government area. Ogun State Nigeria. Archives of Applied Science Research. 2011;3(2):253-65.

44. Azubuike SO, Celestina UO. Breast Cancer: The Perspective of Northern Nigerian Women. International journal of preventive medicine. 2015;6:130.

45. Balogun M, Owoaje E. Knowledge and practice of breast self-examination among female traders in Ibadan, Nigeria. Annal of Ibadan Postgraduate Medicine. 2005;3(2):52-6.

46. Bassey R, Irurhe NK, OLowoyeye M, Adeyomoye A, Onajole A. Knowledge attitude and practice of breast self-examination among nursing students in lagos university teaching hospital, Nigeria International Research Journal. 2011;2(6):1232-6.

47. Faronbi J, Abolade J. Breast self examination practices among female secondary school teachers in a rurual community in oyo state, Nigeria. Open Journal of Nursing 2012;2:111-5.

48. Gwarzo UM, Sabitu K, Idris SH. Knowledge and practice of breast-self examination among female undergraduate students of Ahmadu Bello University Zaria, northwestern Nigeria. Ann Afr Med. 2009;8(1):55-8.

49. Ibrahim NA, Odusanya OO. Knowledge of risk factors, beliefs and practices of female healthcare professionals towards breast cancer in a tertiary institution in Lagos, Nigeria. BMC Cancer. 2009;9:76.

50. Irurhe S, Raji O, Olowoyeye A, Adeyomoye A, Arogundade O, Soyebi A, et al. Knowledge and awareness of breast cancer among female secondary school students in Nigeria. Academic Journal of Cancer Research 2012;5(1):1-5.

51. Kayode F, Akande T, G O. Knowledge, attitude and practice of breast self examination among female secondary school teachers in Ilorin, Nigeria. European Journal of Scientific Research. 2005;10(3):42-7.

52. Makanjuola O, Amoo O, Ajibade B, Makinde O. Breast cancer: knowledge and practice of breast self examination among women in rural community of Ondo State Nigeria. Journal of Pharmacy and biological sciences 2013;8(1):32-7.

53. Obaji N, Elom H, Agwu U, Nwigwe C, Ezeonu P, Umeora O. Awareness and Practice of Breast SelfExamination among Market Women in Abakaliki, South East Nigeria. Ann Med Health Sci Res. 2013;3(1):7-12.

DOI: http://dx.doi.org/10.4314/ejhs.v27i2.9 
54. Oche M, Ayodele S, Umar A. Breast cancer and mammography: current knowledge attitudes and practices of female health workers in tertiary health institution in Northern Nigeria. Public Health Research. 2012;2(5):114-9.

55. Okobia MN, Bunker CH, Okonofua FE, Osime U. Knowledge, attitude and practice of Nigerian women towards breast cancer: a cross-sectional study. World J Surg Oncol. 2006;4:11.

56. Okolie UV. Breast self examination among female undergraduates in Enugu, Southeast, Nigeria International Journal of Nursing and Midwifery. 2012;4(1):1-7.

57. Oladimeji KE, Tsoka-Gwegweni JM, Igbodekwe FC, Twomey M, Akolo C, Balarabe HS, et al. Knowledge and Beliefs of Breast Self-Examination and Breast Cancer among Market Women in Ibadan, South West, Nigeria. PLoS One. 2015;10(11):e0140904.

58. Oluwole O. Awareness, Knowledge and practice of breast-self examination amongst female health workers in a Nigerian community. Sudan JMS. 2008;3(2).

59. Omotara B, Yahya S, Amodu M, Bimba J. Awareness attitude and practice of rural women regarding breast cancer in Northeast Nigeria. $J$ Community Med Health Educ. 2012;2(5):doi: 10.4172/216-0711.1000148.

60. Salaudeen A, Akande T, Musa O. Knowledge and attitude to breast cancer and breast self examination among female undergraduates in a state in Nigeria. European Journal of Social Sciences 2009;7(3):157-65.

61. Utoo P, Chirdan OO. Knowledge practice and education of clients regardign breast cancer screening among health care workers in Plateau North central Nigeria. Jos Journal of Medicine.6(2):46-9.

62. Chioma CA, S. Knowledge, Attitude and Practice of self-breast examination among the female students of the university of Ibadan, Nigeria. Pakistani Journal of Social Sciences. 2007;4(3):400-2.

63. Aluko JO, Ojelade MF, Sowunmi CO, Oluwatosin OA. Awareness, knowledge and practices of breast cancer screening measures among female postgraduate students of a Nigerian Federal University: a cross-sectional study. African journal of medicine and medical sciences. 2014;43(Suppl 1):79-86.

64. Asuquo MO, E. The role fo health education on breast cancer awareness among university of calabar female undergraduates Journal of Education and Practice. 2015;6(24):151-61.
65. Ezeonu PO, Ajah LO, Onoh RC, Lawani LO, Enemuo VC, Agwu UM. Evaluation of clinical breast examination and breast ultrasonography among pregnant women in Abakaliki, Nigeria. OncoTargets and therapy. 2015;8:1025-9.

66. Adeoti M, Agodirin O, Odu O, Oguntola A, Bello $\mathrm{T}$, Aderounmu A. The role of men in early detection of their spouses' breast lump(s)/cancer. The Nigerian Journal of General Practice. 2011;9(2).

67. Osime OC, Okojie O, Aigbekaen ET, Aigbekaen IJ. Knowledge attitude and practice about breast cancer among civil servants in Benin City, Nigeria. Ann Afr Med. 2008;7(4):192-7.

68. Aderounmu AO, Egbewale BE, Ojofeitimi EO, Fadiora SO, Oguntola AS, Asekun-Olarinmoye EO, et al. Knowledge, attitudes and practices of the educated and non-educated women to cancer of the breast in semi-urban and rural areas of SouthWest, Nigeria. Niger Postgrad Med J. 2006;13(3):182-8.

69. Bellgam HB, Y. Knowledge Attidude and Practice of Breast self examination among women in Rivers State, Nigeria. The Nigerian Health Journal. 2012;12(1):16-8.

70. Ajayi IO, Adewole IF. Breast and cervical cancer screening activities among family physicians in Nigeria. African journal of medicine and medical sciences. 2002;31(4):305-9.

DOI: http://dx.doi.org/10.4314/ejhs.v27i2.9 